\title{
Arsenic sulfide as a potential anti-cancer drug
}

\author{
WENPING DING ${ }^{1 *}$, LIAN ZHANG $^{1 *}$, SUNGKYOUNG KIM $^{1 *}$, WEI TIAN ${ }^{1}$, \\ YINGYING TONG ${ }^{1}$, JIANWEN LIU ${ }^{2}$, YONG MA ${ }^{3}$ and SIYU CHEN ${ }^{1}$

\begin{abstract}
${ }^{1}$ Department of Oncology, Xinhua Hospital Affiliated to Shanghai Jiao Tong University School of Medicine, Shanghai 200092;
${ }^{2}$ State Key Laboratory of Bioreactor Engineering and Shanghai Key Laboratory of New Drug Design, School of Pharmacy,

East China University of Science and Technology, Shanghai 200237; ${ }^{3}$ Department of Dermatology,

Shanghai Third People's Hospital, School of Medicine, Shanghai Jiao Tong University,

Shanghai 201999, P.R. China
\end{abstract}

Received March 14, 2014; Accepted October 6, 2014

DOI: $10.3892 / \mathrm{mmr} .2014 .2838$

\begin{abstract}
Arsenic sulfide $\left(\mathrm{As}_{4} \mathrm{~S}_{4}\right)$ is the main component of realgar, which is widely used in traditional Chinese medicine. Previous studies have shown the beneficial effects of $\mathrm{As}_{4} \mathrm{~S}_{4}$ in the treatment of hematological malignant diseases, however, its effects on solid tumors have yet to be fully elucidated. The current study aimed to explore the anti-cancer effect and the mechanism of $\mathrm{As}_{4} \mathrm{~S}_{4}$ on solid tumors in vitro and in vivo. Cells from four human solid tumor cell lines, including the MKN45 gastric cancer cell line, the A375 malignant melanoma cell line, the 8898 pancreatic carcinoma cell line and the HepG2 hepatocellular carcinoma cell line, were treated with $\mathrm{As}_{4} \mathrm{~S}_{4}$ in vitro, using the L02 embryonic liver cells as a control. The efficacy of $\mathrm{As}_{4} \mathrm{~S}_{4}$ was assessed in vivo using mice implanted with Lewis lung carcinoma cells. The results of the current study demonstrated that $\mathrm{As}_{4} \mathrm{~S}_{4}$ significantly inhibited the proliferation of solid tumor cells in a dose- and time-dependent manner, but produced a less pronounced effect on L02 cells. Additionally, $\mathrm{As}_{4} \mathrm{~S}_{4}$ was observed to induce apoptosis (including morphological changes and an enhanced sub- $\mathrm{G}_{1}$ population), which was accompanied by the activation of caspase-3 and -9 . Furthermore, treatment with $\mathrm{As}_{4} \mathrm{~S}_{4}$ significantly inhibited the growth of implanted tumors in mice. These results suggest that $\mathrm{As}_{4} \mathrm{~S}_{4}$ possesses potent in vitro and in vivo antitumor activity via the induction of cell apoptosis.
\end{abstract}

Correspondence to: Dr Yong Ma, Department of Dermatology, Shanghai Third People's Hospital, School of Medicine, Shanghai Jiao Tong University, 280 Mohe Road, Shanghai 201999, P.R. China E-mail: mayong@126.com

Dr Siyu Chen, Department of Oncology, Xinhua Hospital Affiliated to Shanghai Jiao Tong University School of Medicine, 1665 Kongjiang Road, Shanghai 200092, P.R. China

E-mail: siyu.chen@shsmu.edu.cn

Contributed equally

Key words: arsenic sulfide, anti-cancer activity, solid tumor

\section{Introduction}

As a traditional Chinese medicine, arsenic has been widely used for over 2,000 years. It is effectively used in traditional remedies for the treatment of inflammation, ulcers, convulsions and schistosomiasis, and studies have demonstrated that arsenic produces positive effects in cancer therapy (1-3). One study demonstrated that arsenic trioxide $\left(\mathrm{As}_{2} \mathrm{O}_{3}\right)$ was clinically effective in patients with acute promyelocytic leukemia (APL) (4). $\mathrm{As}_{2} \mathrm{O}_{3}$ was approved for the therapy of APL in the year 2000, and subsequently has been widely used therapeutically in liver, cervical and esophageal solid tumors (5-7). A number of studies have demonstrated that the induction of apoptosis and inhibition of proliferation are involved in the antitumor mechanism of $\mathrm{As}_{2} \mathrm{O}_{3}$ in hematopoietic malignancies and solid tumors (8-11).

Arsenic sulfide $\left(\mathrm{As}_{4} \mathrm{~S}_{4}\right)$, another arsenic compound, is the main active component of realgar, an orange-red crystalline mineral that has been extensively used in traditional Chinese medicine. Compared with $\mathrm{As}_{2} \mathrm{O}_{3}, \mathrm{As}_{4} \mathrm{~S}_{4}$ is less toxic, but may elicit a similar anti-neoplastic action. The therapeutic potential of arsenic sulfide in malignancies, particularly hematopoietic tumors, has been the focus of a number of studies (12-15). Its antitumor effects are associated with the inhibition of proliferation, apoptosis and the suppression of BCR-ABL oncoprotein activity $(16,17)$. However, the action of $\mathrm{As}_{4} \mathrm{~S}_{4}$ as a treatment for solid tumor is unclear. Thus, the aim of the current study was to investigate the role of $\mathrm{As}_{4} \mathrm{~S}_{4}$ in the treatment of solid tumors and its potential as an anticancer agent. In the present study, the anti-cancer effects of $\mathrm{As}_{4} \mathrm{~S}_{4}$ were investigated in vitro and in vivo.

\section{Materials and methods}

Materials. A total of $6 \mathrm{~g} \mathrm{As}_{4} \mathrm{~S}_{4}$ was dissolved in $200 \mathrm{ml}$ RPMI 1640 medium (Gibco Life Technologies, Carlsbad, CA, USA) for $12 \mathrm{~h}$, then the concentration of arsenic was measured by atomic absorption spectrometry (IRIS 1000, Thermo, Waltham, MA, USA). The 3-(4,5-dimethylthiazol-2-yl)-2,5-diphenyltetrazolium bromide (MTT) was purchased from Sigma-Aldrich (St. Louis, MO, USA). 
Cells and animals. The MKN45 gastric cancer, A375 malignant melanoma, 8898 pancreatic carcinoma, HepG2 hepatocellular carcinoma and L02 embryonic liver cell lines were purchased from the cell bank of the Type Culture Collection of The Chinese Academy of Sciences (Shanghai, China). All cells were cultured in RPMI 1640 medium supplemented with $10 \%$ heat-inactivated fetal bovine serum (FBS; Gibco Life Technologies), penicillin (100 U/ml) and streptomycin (100 U/ml; both Gibco Life Technologies). Cells were incubated at $37^{\circ} \mathrm{C}$ in a humidified atmosphere of $95 \%$ air and $5 \% \mathrm{CO}_{2}$. Male C57BL/6 mice $(\mathrm{n}=32$; age, six weeks), were obtained from the Animal Center of Fudan University (Shanghai, China; license no., 2007-0002 SCXK). Mice implanted with Lewis lung carcinoma (LLC) cells were purchased from the Institute of Materia Medica, Chinese Academy of Sciences (Shanghai, China; license no., SCXK 2004-0002). Mice were maintained in an animal facility under pathogen-free conditions (license no., SYXK 2003-0031). This study was approved by the ethics committee of Xin Hua Hospital Affiliated to Shanghai Jiao Tong University School of Medicine (Shanghai, China).

Cytotoxicity assay. The cytotoxicity assay was performed using MTT. Cells were seeded into and allowed to attach to 96 -well culture plates $\left(1 \times 10^{4}\right.$ cells/well), for $4 \mathrm{~h}$ prior to treatment. $\mathrm{As}_{4} \mathrm{~S}_{4}$ at concentrations of $0,1.25,2.5,5$ and $10 \mu \mathrm{g} / \mathrm{ml}$ was administered to the cells. After 24-h treatment, cell viability was evaluated by MTT assay. MTT solution (20 $\mu \mathrm{l}$; Sigma-Aldrich) was added to each well and the plates were incubated for an additional $4 \mathrm{~h}$ at $37^{\circ} \mathrm{C}$. The supernatant from each well was then carefully removed, and $100 \mu \mathrm{l}$ dimethyl sulfoxide (Sigma-Aldrich) was added to each well and thoroughly mixed. The optical density (OD) was measured on a Model 550 microplate reader (Bio-Rad Laboratories, Hercules, CA, USA) at an absorbance wavelength of $492 \mathrm{~nm}$ and a reference wavelength of $630 \mathrm{~nm}$. It was denoted that the percentage of cell viability $=$ (average OD of experimental group/average OD of control group) x $100 \%$. The experiment was repeated three times. The $\mathrm{IC}_{50}$ (concentration causing $50 \%$ inhibition of cell growth compared with the control) value of $\mathrm{As}_{4} \mathrm{~S}_{4}$ for each of the tumor cell lines was also calculated after $24 \mathrm{~h}$.

Determination of time-activity curve. The effect of $\mathrm{As}_{4} \mathrm{~S}_{4}$ on cell viability was determined by measuring the MTT absorbance of living cells, which were seeded in and allowed to attach to 96-well plates. Following 0, 6, 12, 24, 36 and $48 \mathrm{~h}$ incubation of the tumor cells with $\mathrm{As}_{4} \mathrm{~S}_{4}\left(\right.$ at $\mathrm{IC}_{50}$ ) while L02 cells with $10 \mu \mathrm{g} / \mathrm{ml} \mathrm{As}_{4} \mathrm{~S}_{4}$, the cell viability was evaluated by MTT assay. The experiment was repeated three times.

Hematoxylin and eosin (HE) staining assay. Cells from exponentially growing cultures were seeded in 24-well culture plates and treated with $\mathrm{As}_{4} \mathrm{~S}_{4}\left(\right.$ at $\left.\mathrm{IC}_{50}\right)$ for $36 \mathrm{~h}$, and L02 cells were treated with $10 \mu \mathrm{g} / \mathrm{ml} \mathrm{As}_{4} \mathrm{~S}_{4}$. Cells were washed with phosphate-buffered saline (PBS; Gibco Life Technologies), fixed in 4\% paraformaldehyde (Sigma-Aldrich) for $15 \mathrm{~min}$, stained with hematoxylin (Beyotime Institute of Biotechnology, Jiangsu, China) for $8 \mathrm{~min}$, washed again with PBS, stained with eosin (Beyotime Institute of Biotechnology) for $5 \mathrm{~min}$, and then examined and imaged with with the Nikon Eclipse 55i microscope (Nikon Corporation, Tokyo, Japan).

Flow cytometric analysis of cellular DNA content. Three cell lines (A375, MKN45 and L02) were seeded in 6-well culture plates ( $2 \times 10^{5}$ cells/well). Following 12-h incubation, A375 and MKN45 cells were treated with the respective $\mathrm{IC}_{50}$ of $\mathrm{As}_{4} \mathrm{~S}_{4}$ for $36 \mathrm{~h}$, and L02 cells were treated with $10 \mu \mathrm{g} / \mathrm{ml} \mathrm{As}_{4} \mathrm{~S}_{4}$. Floating and attached cells were collected in centrifuge tubes. Cells were washed with PBS, then resuspended and fixed in $70 \%$ ice-cold ethanol (Yangyuan, Changshu, China) for $4 \mathrm{~h}$ at $4^{\circ} \mathrm{C}$. Subsequently, they were treated with RNase A $(50 \mu \mathrm{g} / \mathrm{ml}$; Sigma-Aldrich) for $30 \mathrm{~min}$. Cells were stained with propidium iodide $(50 \mu \mathrm{g} / \mathrm{ml})$, then analyzed in a flow cytometer (BD Accuri C6, BD Biosciences, Franklin Lakes, NJ, USA). The percentages of cells in the $G_{0} / G_{1}, S, G_{2} / M$ and sub- $G_{1}$ phases were analyzed using standard ModiFit LT 3.1and CellQuest Pro software (BD, Mac OS X.1; San Jose, CA, USA).

Lactate dehydrogenase $(\mathrm{LDH})$ release assay. The $\mathrm{A} 375$ and MKN45 cells were treated with the respective $\mathrm{IC}_{50}$ doses of $\mathrm{As}_{4} \mathrm{~S}_{4}$, and L02 cells were treated with $10 \mu \mathrm{g} / \mathrm{ml} \mathrm{As} \mathrm{S}_{4}$. After $36 \mathrm{~h}$, supernatants were harvested to measure the levels of LDH using the LDH kit (BHKT Clinical Reagent Co., Beijing, China)

Caspase activity assay. MKN45 cells were seeded in $10-\mathrm{cm}$ dishes. Following a resting period of $12 \mathrm{~h}$, cells were treated with various concentrations $\left(0 \mu \mathrm{g} / \mathrm{ml}, 0.25 \times \mathrm{IC}_{50}\right.$, $0.5 \times \mathrm{IC}_{50}, 1 \times \mathrm{IC}_{50}$ ) of $\mathrm{As}_{4} \mathrm{~S}_{4}$ for $36 \mathrm{~h}$. Following treatment, the cells (floating and attached) were collected and washed three times with PBS and resuspended in $50 \mathrm{mM}$ Tris- $\mathrm{HCl}$ (pH 7.4; Sigma-Aldrich), 1 mM EDTA (Sigma-Aldrich) and $10 \mathrm{mM}$ ethyleneglycoltetraacetic acid (Sigma-Aldrich). Cell lysates were clarified by centrifugation at $18,000 \mathrm{x} \mathrm{g}$ for $3 \mathrm{~min}$ and clear lysates containing $50 \mu \mathrm{g}$ protein were incubated with $100 \mu \mathrm{M}$ enzyme-specific colorigenic substrates (Ac-DEVD-pNA; Beyotime Institute of Biotechnology) at $37^{\circ} \mathrm{C}$ for $1 \mathrm{~h}$. The activity of caspase- 3 and -9 was denoted as the cleavage of colorimetric substrate measured at an absorbance of $405 \mathrm{~nm}$.

In vivo experiments with C57BL/6 mice. The mice implanted with LLC cells were sacrificed by cervical dislocation. Under sterile conditions, tumor tissues were dissected and the tumor cells were suspended in RPMI 1640 medium containing $10 \%$ FBS. The cell suspension was injected into the flanks of the experimental mice $\left(10^{6}\right.$ cells in $200 \mu \mathrm{l}$ PBS for each mouse). The tumor-bearing mice were divided into four groups: Negative control (NC) group, positive control group and high- and low- dose groups, each containing eight mice. The tumor-bearing mice were administered with an intraperitoneal injection of either 30 (low) or 60 (high) mg/kg dose of $\mathrm{As}_{4} \mathrm{~S}_{4}$, daily for eight days. The NC group was treated with $0.9 \%$ normal saline (Rongbai, Shanghai, China) and the positive group was treated with $20 \mathrm{mg} / \mathrm{kg}$ cyclophosphamide (CTX; Yili, Shanghai, China), respectively. Subsequent to euthanization, the solid tumors were harvested and weighed, and blood was drawn to measure the level of interleukin-2 (IL-2). The solid tumor weights were statistically analyzed. 
The rate of inhibition (RI) was calculated according to the following formula: $\mathrm{RI}=[$ (mean tumor weight of the NC group - mean tumor weight of the drug group)/mean tumor weight of the NC group] x $100 \%$.

Statistical analysis. Each experimental value was expressed as the mean \pm standard deviation. Statistical analysis was performed using Origin software, version 7.0 (OriginLab, Northampton, MA, USA) to evaluate the differences between groups. $\mathrm{P}<0.05$ was considered to indicate a statistically significant difference.

\section{Results}

Cytotoxic effect of $A s_{4} S_{4}$ on tumor cells. The cytotoxicity assay results for $\mathrm{As}_{4} \mathrm{~S}_{4}$ on the five cell lines are presented in Fig. 1. The data indicated that the cell proliferation was inhibited by $\mathrm{As}_{4} \mathrm{~S}_{4}$ in a dose-dependent (Fig. 1A) and time-dependent (Fig. 1B) manner $(\mathrm{P}<0.001)$, and each cell line presented a different sensitivity to the inhibitory effect of $\mathrm{As}_{4} \mathrm{~S}_{4}$. The $\mathrm{IC}_{50}$ values of the tumor cell lines following 24-h treatment are presented in Table I. $\mathrm{As}_{4} \mathrm{~S}_{4}$ generated a weaker effect on L02 cells compared with the four tumor cell lines.

Effect of $\mathrm{As}_{4} \mathrm{~S}_{4}$ on cell morphology. The HE staining assay identified that the tumor cells (8898, A375, HepG2 and MKN45) treated with $\mathrm{As}_{4} \mathrm{~S}_{4}$ exhibited cell shrinkage, nuclear condensation and fragmentation, which are typical characteristics of apoptosis. However, the treated L02 cells did not exhibit significant morphological changes (Fig. 2).

Effect of $\mathrm{As}_{4} \mathrm{~S}_{4}$ on $G_{2} / M$ phase arrest and the apoptotic sub-G $G_{1}$ population. To determine whether the reduction in cell viability observed involved alterations to the cell cycle, the effect of $\mathrm{As}_{4} \mathrm{~S}_{4}$ on the cell cycle distribution in the A375, MKN45 and L02 cell lines was investigated using fluorescence-activated cell sorting analysis (Fig. 3A). The apoptotic index was calculated by measuring the number of cells in the sub- $\mathrm{G}_{1}$ population following treatment with $\mathrm{As}_{4} \mathrm{~S}_{4}$. Subsequent to exposure of A375, MKN45 cells to the respective $\mathrm{IC}_{50} \mathrm{~S}$ of $\mathrm{As}_{4} \mathrm{~S}_{4}$ and of L02 cells to $10 \mu \mathrm{g} / \mathrm{ml}$ $\mathrm{As}_{4} \mathrm{~S}_{4}$ for $36 \mathrm{~h}$, no marked $\mathrm{G}_{2} / \mathrm{M}$ phase arrest was observed, as demonstrated in Fig. 3B. These results suggest that $\mathrm{As}_{4} \mathrm{~S}_{4}$ produced no significant effect on $\mathrm{G}_{2} / \mathrm{M}$ phase arrest. A significant increase in the sub- $\mathrm{G}_{1}$ fraction was identified in tumor cells treated with $\mathrm{As}_{4} \mathrm{~S}_{4}$, whilst no significant difference was observed in the L02 cells compared with the untreated control cells (Fig. 3C).

Effect of $\mathrm{As}_{4} \mathrm{~S}_{4}$ on the level of $\mathrm{LDH}$ and the activation of caspase. The LDH release assay measured the leakage of $\mathrm{LDH}$ into the extracellular medium following cellular lysis. The release of intracellular LDH was detected following exposure to $\mathrm{As}_{4} \mathrm{~S}_{4}$ (Fig. 4A). Meanwhile, caspase-3 and -9 were activated in MKN45 cells treated with $\mathrm{As}_{4} \mathrm{~S}_{4}$ for $36 \mathrm{~h}$ (Fig. 4B). These results indicate the involvement of caspase-3 and -9 in $\mathrm{As}_{4} \mathrm{~S}_{4}$-mediated cell apoptosis.

$A s_{4} S_{4}$ inhibits the growth of solid tumors and elevates the levels of IL-2 in blood. Mouse lung cancer LLC cells were
Table $\mathrm{I} \mathrm{IC}_{50}$ value of arsenic sulfide for each tumor cell line following 24-h treatment.

\begin{tabular}{lc}
\hline Cell line & $\begin{array}{c}\mathrm{IC}_{50}(\mu \mathrm{g} / \mathrm{ml}) \\
\mathrm{x} \pm \text { standard deviation }\end{array}$ \\
\hline HepG2 & $6.89 \pm 1.078$ \\
MKN45 & $9.37 \pm 0.948$ \\
8898 & $9.06 \pm 0.984$ \\
A375 & $3.78 \pm 0.827$ \\
\hline
\end{tabular}

$\mathbf{A}$

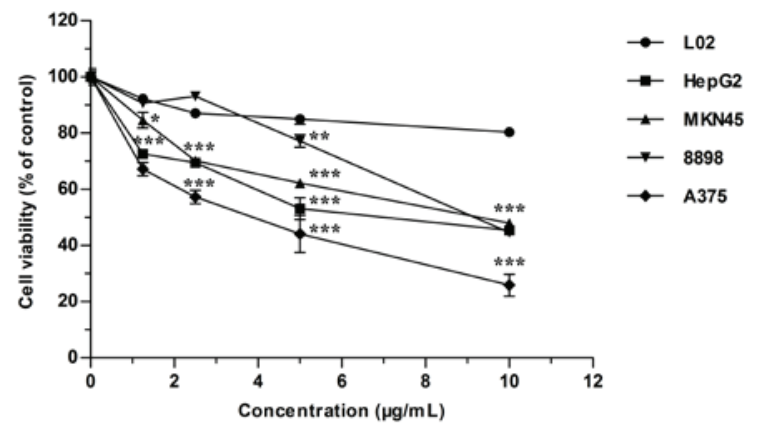

B

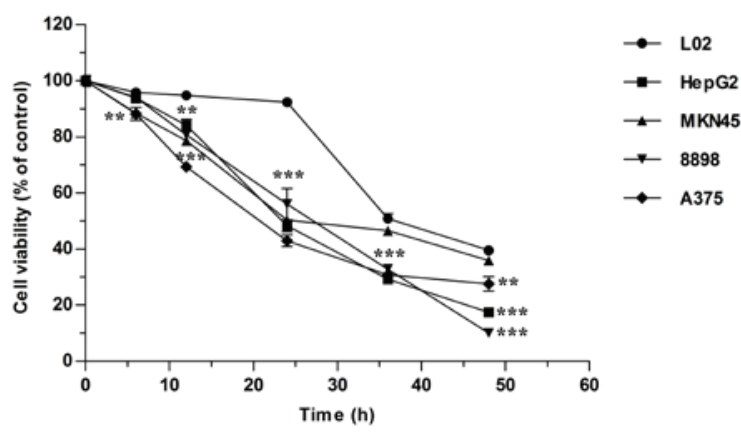

Figure 1. Cytotoxic effect of $\mathrm{As}_{4} \mathrm{~S}_{4}$ on 8898, A375, HepG2 and MKN45 cancer cells and L02 healthy liver cells. (A) Viability of the cells was measured by MTT assay following exposure to $\mathrm{As}_{4} \mathrm{~S}_{4}$ at different concentrations $(1.25-10 \mu \mathrm{g} / \mathrm{ml})$ for $24 \mathrm{~h}$. (B) Measurement of cell viability following treatment with the respective $\mathrm{IC}_{50} \mathrm{~S}$ of $\mathrm{As}_{4} \mathrm{~S}_{4}$ for each tumor cell line for different time periods ( $0-48 \mathrm{~h}$ ) ( $\mathrm{L} 02$ cells were treated with $10 \mu \mathrm{g} / \mathrm{ml} \mathrm{As}_{4} \mathrm{~S}_{4}$ ). Data are expressed as the mean \pm standard deviation. The cell proliferation was inhibited by $\mathrm{As}_{4} \mathrm{~S}_{4}$ in an (A) dose-dependent and (B) time-dependent manner $(\mathrm{P}<0.001)$ and each cell line presented a different sensitivity to the inhibitory effect of $\mathrm{As}_{4} \mathrm{~S}_{4}\left({ }^{*} \mathrm{P}<0.05\right.$, ${ }^{* *} \mathrm{P}<0.01$ and $^{* * * *} \mathrm{P}<0.001$, vs. L02 cells). $\mathrm{As}_{4} \mathrm{~S}_{4}$, arsenic sulfide.

implanted in C57BL/6 mice. Following treatment with $\mathrm{As}_{4} \mathrm{~S}_{4}$ for eight days, the suppression of tumor growth was observed (Fig. 5A). The inhibition ratios of the low-dose group $\left(\mathrm{As}_{4} \mathrm{~S}_{4}, 30 \mathrm{mg} / \mathrm{kg}\right)$ and high-dose group $\left(\mathrm{As}_{4} \mathrm{~S}_{4}\right.$, $60 \mathrm{mg} / \mathrm{kg}$ ) were 26.45 and $47.93 \%$, respectively (Table II). The high dosage exhibited a greater anticancer effect than the low dosage, and produced a significantly reduced tumor weight compared with that of the NC group. In addition, $\mathrm{As}_{4} \mathrm{~S}_{4}$ treatment did not significantly alter the body weight of the mice (data not shown). Subsequent to treatment with $\mathrm{As}_{4} \mathrm{~S}_{4}$, the concentrations of IL-2 in the treatment groups were higher compared with the NC group (Fig. 5B). These results demonstrate that $\mathrm{As}_{4} \mathrm{~S}_{4}$ is able to suppress tumor growth. 


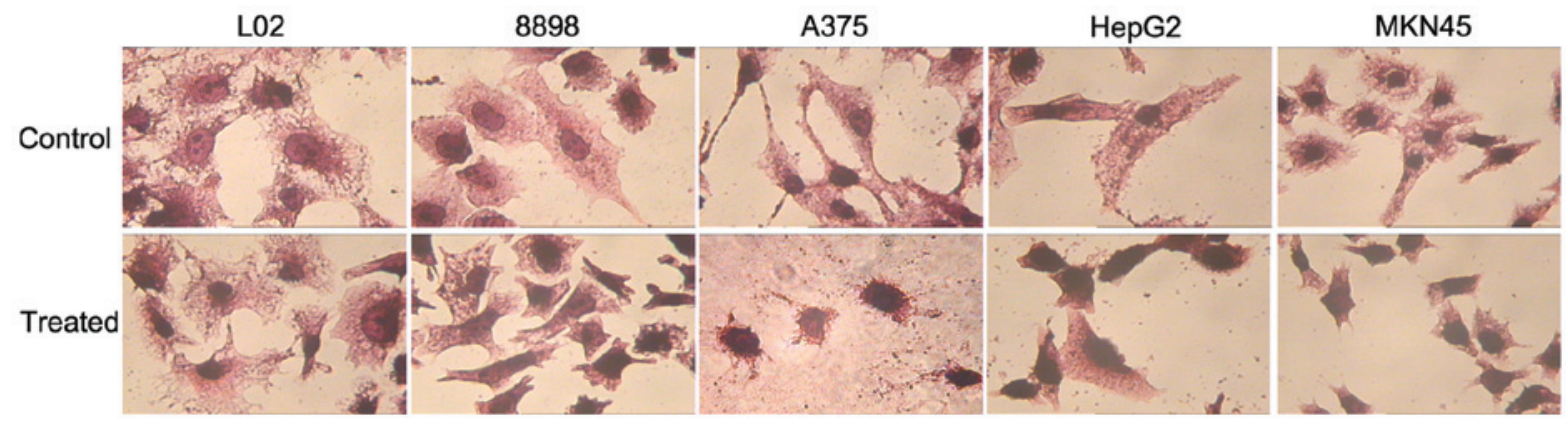

Figure 2. Hematoxylin and eosin staining of 8898, A375, HepG2 and MKN45 cells cultured in the presence or absence of the respective $\mathrm{IC}_{50} \mathrm{~s}$ of $\mathrm{As}_{4} \mathrm{~S}_{4}$ for $36 \mathrm{~h}$ and L02 cells treated with $10 \mu \mathrm{g} / \mathrm{ml} \mathrm{As}_{4} \mathrm{~S}_{4}$. Condensed and fragmented nuclei were observed in the $\mathrm{As}_{4} \mathrm{~S}_{4}$-treated tumor cells, but not in the L02 cells. Magnification, $\mathrm{x} 400 . \mathrm{As}_{4} \mathrm{~S}_{4}$, arsenic sulfide.
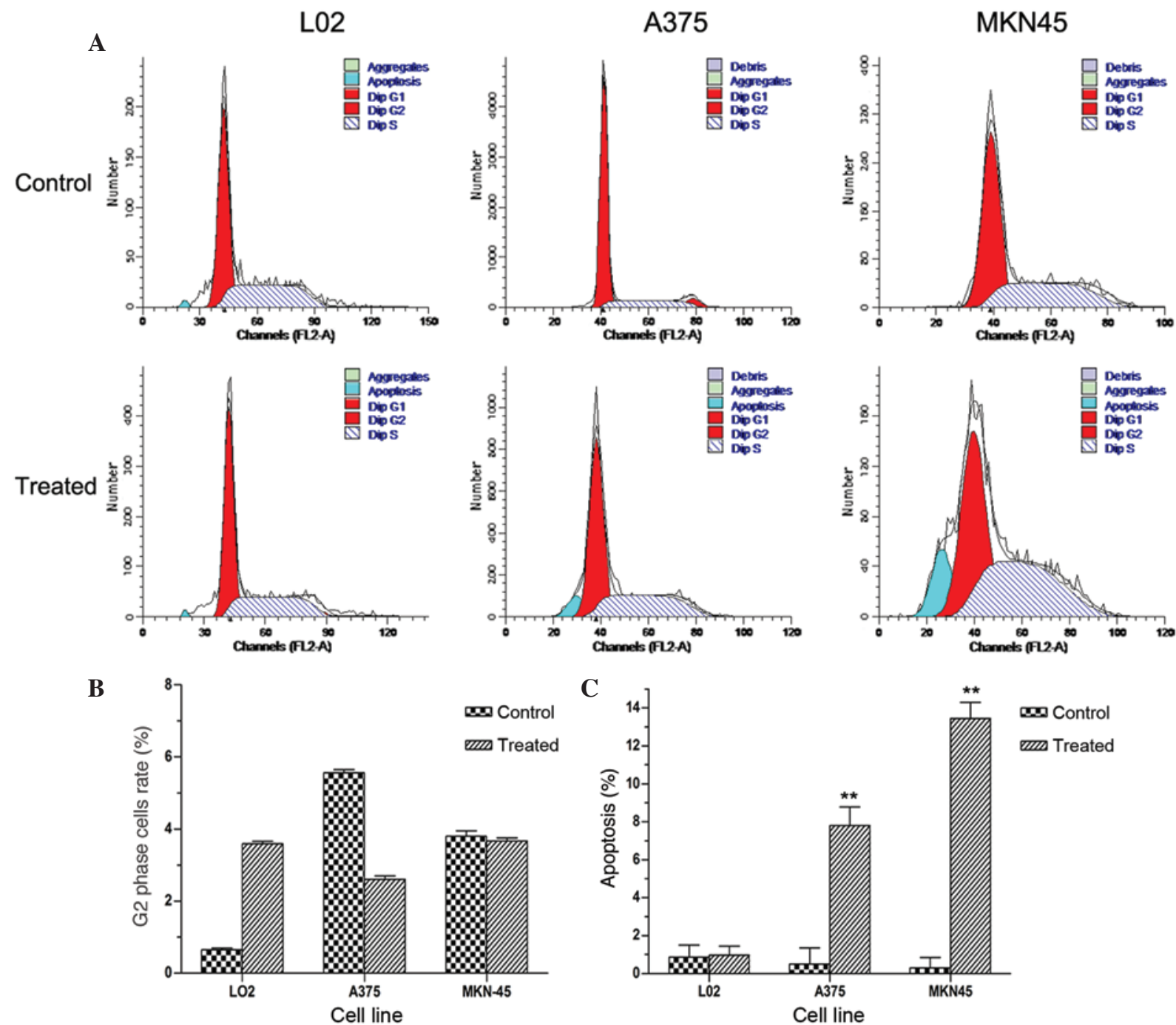

Figure 3. Effect of $\mathrm{As}_{4} \mathrm{~S}_{4}$ on $\mathrm{G}_{2} / \mathrm{M}$ phase and apoptotic cells. (A) L02, A375 and MKN45 cells were treated with or without As $\mathrm{S}_{4}$ and analyzed by flow cytometry. (B) Data indicated no clear $\mathrm{G}_{2} / \mathrm{M}$ phase arrest in the tumor or L02 cells treated with $\mathrm{As}_{4} \mathrm{~S}_{4}$. (C) A significant increase in apoptotic sub G1 population was observed in $\mathrm{As}_{4} \mathrm{~S}_{4}$-treated A375 and MKN45 cells, but not in the L02 cells. Data are expressed as the mean \pm standard deviation; " $\mathrm{P}<0.05$, "** $\mathrm{P}<0.01$ and ${ }_{* * * *} \mathrm{P}<0.001$ vs. control. $\mathrm{As}_{4} \mathrm{~S}_{4}$, arsenic sulfide.

\section{Discussion}

$\mathrm{As}_{4} \mathrm{~S}_{4}$ has attracted worldwide interest in recent years due to the successful clinical application of arsenic compounds in the treatment of APL $(12,18)$. However, its efficacy in the treatment of solid tumors remains to be thoroughly elucidated. Hence, in the present study, the antitumor effect of $\mathrm{As}_{4} \mathrm{~S}_{4}$ on solid tumors and its possible mechanism of action were investigated.

Apoptosis, the most common form of tumor cell death, is a biological process of programmed cell death (PCD). The 
Table II. Antitumor effect of $\mathrm{As}_{4} \mathrm{~S}_{4}$ in vivo.

Injection dosage $(\mathrm{mg} / \mathrm{kg})$

Group

$\mathrm{x} \pm$ standard deviation

Tumor weight $(\mathrm{g})$

Tumor inhibition (\%)

\begin{tabular}{lccc}
\hline Negative control & 0 & $2.42 \pm 0.73$ & 0 \\
Positive control (cyclophosphamide) & 20 & $0.59 \pm 0.16^{\mathrm{b}}$ & 75.62 \\
High $\mathrm{As}_{4} \mathrm{~S}_{4}$ & 60 & $1.26 \pm 0.54^{\mathrm{a}}$ & 47.93 \\
Low $\mathrm{As}_{4} \mathrm{~S}_{4}$ & 30 & $1.78 \pm 0.55$ & 26.45 \\
\hline
\end{tabular}

C57BL/6 mice were inoculated with Lewis lung carcinoma cells ( $10^{6}$ cells/mouse), injected intraperitoneally with As $\mathrm{S}_{4}$ for eight days and subsequently sacrificed. Data are expressed as the mean \pm standard deviation. ${ }^{a} \mathrm{P}<0.01 ;{ }^{b} \mathrm{P}<0.001 \mathrm{vs}$. negative control. As $\mathrm{S}_{4}$, arsenic sulfide.

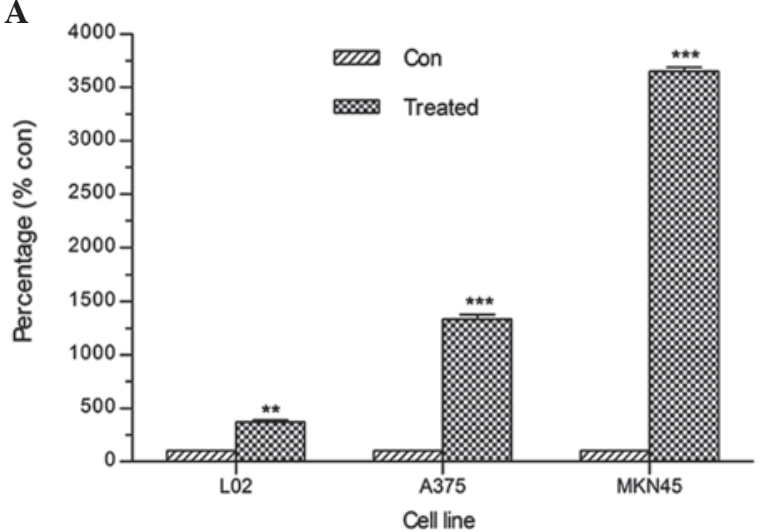

B

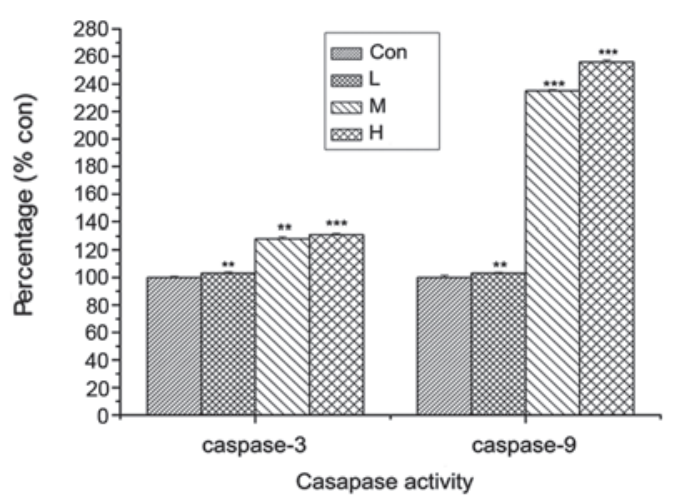

Figure 4. Effect of $\mathrm{As}_{4} \mathrm{~S}_{4}$ on the release of LDH and the activation of caspase-3 and -9. (A) Subsequent to exposure of A375 and MKN45 cells to the respective $\mathrm{IC}_{50} \mathrm{~S}$ of $\mathrm{As}_{4} \mathrm{~S}_{4}$ for $36 \mathrm{~h}$, and exposure of $\mathrm{L} 02$ cells to $10 \mu \mathrm{g} / \mathrm{ml} \mathrm{As} \mathrm{S}_{4}$, the leakage of $\mathrm{LDH}$ from cells was analyzed. (B) Caspase- 3 and -9 activation was analyzed in MKN45 cells treated with different concentrations of $\mathrm{As}_{4} \mathrm{~S}_{4}$ for $36 \mathrm{~h}$ : Control, $0 \mu \mathrm{g} / \mathrm{ml} ; \mathrm{L}, 0.25 \times \mathrm{IC}_{50} ; \mathrm{M}, 0.5 \times \mathrm{IC}_{50}$ and $\mathrm{H}, 1 \times \mathrm{IC}_{50}$. Data are expressed as the mean \pm standard deviation; ${ }^{P} \mathrm{P}<0.05,{ }^{* *} \mathrm{P}<0.01$ and ${ }^{* * * *} \mathrm{P}<0.001$ vs. control. $\mathrm{As}_{4} \mathrm{~S}_{4}$, arsenic sulfide; $\mathrm{LDH}$, lactate dehydrogenase; L, low; $\mathrm{M}$, medium; H, high.

A

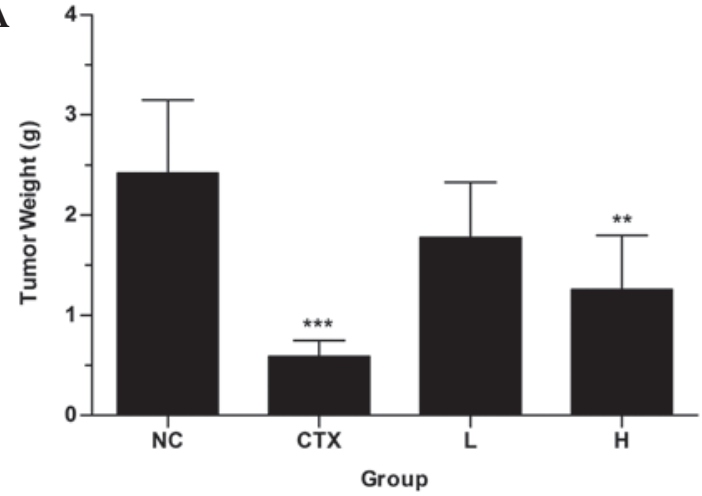

B

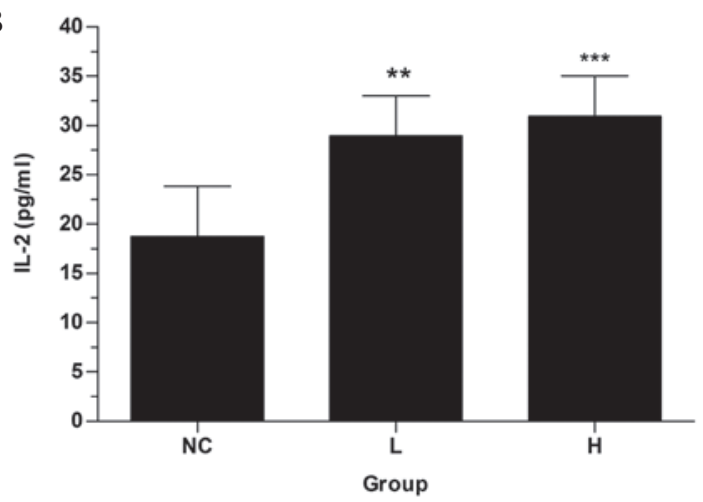

Figure 5. $\mathrm{As}_{4} \mathrm{~S}_{4}$ inhibited tumor growth and elevated the levels of IL-2 in the tumor-bearing C57BL/6 mice. (A) Tumor weight reduced significantly following treatment with $60 \mathrm{mg} / \mathrm{kg}(\mathrm{H})$ of $\mathrm{As}_{4} \mathrm{~S}_{4}$, but the reduction observed was not significant with $30 \mathrm{mg} / \mathrm{kg}$ (L). (B) Levels of IL-2 were significantly elevated in the treatment groups compared with the $\mathrm{NC}$ group. Data are expressed as the mean \pm standard deviation; ${ }^{*} \mathrm{P}<0.05,{ }^{* * *} \mathrm{P}<0.01$ and ${ }^{* * * *} \mathrm{P}<0.001$ vs. $\mathrm{NC}$. As $\mathrm{S}_{4}$, arsenic sulfide; IL-2, interleukin 2; L, low; H, high; NC, negative control; CTX, cyclophosphamide.

typical morphological and molecular changes that occur during the course of apoptosis include cell shrinkage, nuclear fragmentation, chromatin condensation, DNA fragmentation and changes in apoptotic protein expression (19-21). In the current study, using MTT assay, $\mathrm{As}_{4} \mathrm{~S}_{4}$ was observed to be able to inhibit the proliferation of tumor cells in a dose- and time-dependent manner, but produced a less marked effect on healthy L02 cells, which were used as a control to assess the hepatotoxicity of
$\mathrm{As}_{4} \mathrm{~S}_{4}$. Flow cytometry indicated that the inhibition of A375 and MKN45 tumor cell growth by $\mathrm{As}_{4} \mathrm{~S}_{4}$ may be due to cell apoptosis. However, no significant effect of $\mathrm{As}_{4} \mathrm{~S}_{4}$ on $\mathrm{G}_{2} / \mathrm{M}$ phase arrest was observed. The HE staining assay demonstrated that four tumor cell lines treated with the $\mathrm{IC}_{50}$ of $\mathrm{As}_{4} \mathrm{~S}_{4}$ for $36 \mathrm{~h}$ exhibited cell shrinkage, nuclear condensation and fragmentation (typical characteristics of apoptosis), while L02 cells treated with $\mathrm{As}_{4} \mathrm{~S}_{4}$ demonstrated no differences prior to and post administration. 
LDH is clinically significant as a marker of injury and disease, since it is released during cell or tissue damage. The LDH release assay measures the leakage of the soluble cytoplasmic LDH enzyme into the extracellular medium via cellular lysis. The current study demonstrated that $\mathrm{As}_{4} \mathrm{~S}_{4}$ increased the release of $\mathrm{LDH}$, indicating the induction of apoptosis or necrosis.

Caspases are cysteine proteases activated by a cascade, involving the cleavage of their precursors. Caspase- 3 is an executioner caspase that disassembles cells through the cleavage of proteins such as PARP, in order to inactivate them. Caspase-3 is commonly activated by either the caspase-9-mediated mitochondrial pathway, or by the caspase-8-mediated death receptor pathway (22-24). In the current study, $\mathrm{As}_{4} \mathrm{~S}_{4}$ treatment was demonstrated to lead to caspase-3 and -9 activation, which suggests the involvement of the caspase pathways in $\mathrm{As}_{4} \mathrm{~S}_{4}$-induced apoptosis.

The antitumor activity of $\mathrm{As}_{4} \mathrm{~S}_{4}$ was further examined in a mouse model. Similar to the in vitro results, $\mathrm{As}_{4} \mathrm{~S}_{4}$ was capable of inhibiting tumor growth in vivo. In the high dosage group, the tumors grew slower compared to the NC group. However, $\mathrm{As}_{4} \mathrm{~S}_{4}$ did not produce a significant inhibitory effect on tumor growth in the low $\mathrm{As}_{4} \mathrm{~S}_{4}$ dosage group compared with the $\mathrm{NC}$ group.

Studies have demonstrated that IL-2 serves an important function in the regulation of antigen-specific T-cell responses $(25,26)$. The cytokines expressed by a T-cell in response to an antigen indicate the specific pathway, and IL-2 is associated with the T helper 1 (Th1) pathway. IL-2 has been demonstrated to serve an important role in specific immunological responses to tumor cell growth $(27,28)$. Thus, in the present study, IL-2 production was investigated to evaluate the hypothesis that $\mathrm{As}_{4} \mathrm{~S}_{4}$ increases T-cell activation by modulating IL-2. The results demonstrated that the serum concentrations IL-2 were enhanced in $\mathrm{As}_{4} \mathrm{~S}_{4}$-treated C57BL/6 mice bearing LLC, compared with the NC mice, suggesting that it may be a potent inducer of Th1-type cytokines.

In the present study, $\mathrm{As}_{4} \mathrm{~S}_{4}$ was observed to induce apoptosis in cancer cells. The detailed mechanism of apoptosis induction in solid tumors by $\mathrm{As}_{4} \mathrm{~S}_{4}$ requires further investigation. Previous studies have reported that $\mathrm{As}_{4} \mathrm{~S}_{4}$ treatment induced differentiation of hematological tumor cells $(29,30)$, suggesting that the antitumor action of $\mathrm{As}_{4} \mathrm{~S}_{4}$ in solid tumors may involve cellular differentiation.

In the current study, the results suggested that $\mathrm{As}_{4} \mathrm{~S}_{4}$ may be able to inhibit cell growth and increase the release of $\mathrm{LDH}$. Furthermore, the apoptosis was suggested to involve caspase-3 and -9 activation. Additionally, $\mathrm{As}_{4} \mathrm{~S}_{4}$ was demonstrated to have the effect of suppressing tumor growth in vivo. These results suggest that $\mathrm{As}_{4} \mathrm{~S}_{4}$ may be a potential therapeutic candidate in the treatment of solid tumors.

\section{Acknowledgements}

The current study was supported by the National Natural Science Foundation of China (grant nos. 81274142 and 30300139); the Science and Technology Commission of Shanghai Municipality (grant no. 11ZR1423400); the Key Project of Shanghai Municipal Education Commission (grant no. 07zz43); and Shanghai Jiao Tong University
School of Medicine Foundation of Science and Technology (05XJ21030).

\section{References}

1. Nakagawa Y, Akao Y, Morikawa $\mathrm{H}$, et al: Arsenic trioxide-induced apoptosis through oxidative stress in cells of colon cancer cell lines. Life Sci 70: 2253-2269, 2002.

2. Ramanathan K, Anusuyadevi M, Shila S and Panneerselvam C: Ascorbic acid and alpha-tocopherol as potent modulators of apoptosis on arsenic induced toxicity in rats. Toxicol Lett 156: 297-306, 2005.

3. Waxman S and Anderson KC: History of the development of arsenic derivatives in cancer therapy. Oncologist 6 (Suppl 2): 3-10, 2001.

4. Niu C, Yan H, Yu T, et al: Studies on treatment of acute promyelocytic leukemia with arsenic trioxide: remission induction, follow-up, and molecular monitoring in 11 newly diagnosed and 47 relapsed acute promyelocytic leukemia patients. Blood 94: 3315-3324, 1999.

5. Murgo AJ: Clinical trials of arsenic trioxide in hematologic and solid tumors: overview of the National Cancer Institute Cooperative Research and Development Studies. Oncologist 6 (Suppl 2): 22-28, 2001.

6. Zheng J, Deng YP, Lin C, Fu M, Xiao PG and Wu M: Arsenic trioxide induces apoptosis of HPV16 DNA-immortalized human cervical epithelial cells and selectively inhibits viral gene expression. Int J Cancer 82: 286-292, 1999.

7. Shen ZY, Zhang Y, Chen JY, et al: Intratumoral injection of arsenic to enhance antitumor efficacy in human esophageal carcinoma cell xenografts. Oncol Rep 11: 155-159, 2004.

8. Emadi A and Gore SD: Arsenic trioxide - An old drug rediscovered. Blood Rev 24: 191-199, 2010.

9. Rojewski MT, Baldus C, Knauf W, Thiel E and Schrezenmeier H: Dual effects of arsenic trioxide $\left(\mathrm{As}_{2} \mathrm{O}_{3}\right)$ on non-acute promyelocytic leukaemia myeloid cell lines: induction of apoptosis and inhibition of proliferation. Br J Haematol 116: 555-563, 2002.

10. Park WH, Seol JG, Kim ES, et al: Arsenic trioxide-mediated growth inhibition in MC/CAR myeloma cells via cell cycle arrest in association with induction of cyclin-dependent kinase inhibitor, p21, and apoptosis. Cancer Res 60: 3065-3071, 2000.

11. Zhong F, Zhang S, Shao C, Yang J and Wu X: Arsenic trioxide inhibits cholangiocarcinoma cell growth and induces apoptosis. Pathol Oncol Res 16: 413-420, 2010.

12. Lu DP, Qiu JY, Jiang B, et al: Tetra-arsenic tetra-sulfide for the treatment of acute promyelocytic leukemia: a pilot report. Blood 99: 3136-3143, 2002.

13. Wang L, Zhou GB, Liu P, et al: Dissection of mechanisms of Chinese medicinal formula Realgar-Indigo naturalis as an effective treatment for promyelocytic leukemia. Proc Natl Acad Sci USA 105: 4826-4831, 2008.

14. Zhang QY, Mao JH, Liu P, et al: A systems biology understanding of the synergistic effects of arsenic sulfide and Imatinib in BCR/ABL-associated leukemia. Proc Natl Acad Sci USA 106: 3378-3383, 2009.

15. Chen S, Fang Y, Ma L, Liu S and Li X: Realgar-induced apoptosis and differentiation in all-trans retinoic acid (ATRA)-sensitive NB4 and ATRA-resistant MR2 cells. Int J Oncol 40: 1089-1096, 2012.

16. Yin T, Wu YL, Sun HP, et al: Combined effects of $\mathrm{As}_{4} \mathrm{~S}_{4}$ and imatinib on chronic myeloid leukemia cells and BCR-ABL oncoprotein. Blood 104: 4219-4225, 2004.

17. Wu J, Shao Y, Liu J, Chen G and Ho PC: The medicinal use of realgar $\left(\mathrm{As}_{4} \mathrm{~S}_{4}\right)$ and its recent development as an anticancer agent. J Ethnopharmacol 135: 595-602, 2011.

18. Lu DP and Wang Q: Current study of APL treatment in China. Int J Hematol 76 (Suppl 1): 316-318, 2002.

19. Majno G and Joris I: Apoptosis, oncosis, and necrosis. An overview of cell death. Am J Pathol 146: 3-15, 1995.

20. McConkey DJ and Orrenius S: Signal transduction pathways in apoptosis. Stem Cells 14: 619-631, 1996.

21. Hunot S and Flavell RA: Apoptosis. Death of a monopoly? Science 292: 865-866, 2001.

22. Hengartner M: Apoptosis. Death by crowd control. Science 281: 1298-1299, 1998.

23. Ashkenazi A and Dixit VM: Death receptors: signaling and modulation. Science 281: 1305-1308, 1998.

24. McIlwain DR,BergerT and MakTW: Caspase functions incelldeath and disease. Cold Spring Harb Perspect Biol 5: a008656, 2013. 
25. Smith KA: Interleukin-2: inception, impact, and implications. Science 240: 1169-1176, 1988.

26. Sakaguchi S, Sakaguchi N, Asano M, Itoh M and Toda M: Immunologic self-tolerance maintained by activated $\mathrm{T}$ cells expressing IL-2 receptor alpha-chains (CD25). Breakdown of a single mechanism of self-tolerance causes various autoimmune diseases. J Immunol 155: 1151-1164, 1995.

27. McAdam AJ, Pulaski BA, Harkins SS, Hutter EK, Lord EM and Frelinger JG: Synergistic effects of co-expression of the TH1 cytokines IL-2 and IFN-gamma on generation of murine tumor-reactive cytotoxic cells. Int J Cancer 61: 628-634, 1995.
28. Sakthivel KM and Guruvayoorappan C: Acacia ferruginea inhibits tumor progression by regulating inflammatory mediators-(TNF- $\alpha$, iNOS, COX-2, IL-1 $\beta$, IL-6, IFN- $\gamma$, IL-2, GM-CSF) and pro-angiogenic growth factor-VEGF. Asian Pac J Cancer Prev 14: 3909-3919, 2013

29. Wang LW, Shi YL, Wang N, Gou BD, Zhang TL and Wang K: Association of oxidative stress with realgar-induced differentiation in human leukemia HL-60 cells. Chemotherapy 55: 460-467, 2009.

30. Wang N, Wang LW, Gou BD, Zhang TL and Wang K: Realgar-induced differentiation is associated with MAPK pathways in HL-60 cells. Cell Biol Int 32: 1497-1505, 2008. 